\title{
PENERAPAN MODEL PEMBELAJARAN KAUSALITIK DALAM MENINGKATKAN KREATIVITAS PESERTA DIDIK
}

\author{
Imam Al Anshori*, Joni Rokhmat, I Wayan Gunada \\ Program Studi Pendidikan Fisika, Universitas Mataram \\ *Email: imamalanshory96@gmail.com
}

DOI: http://dx.doi.org/10.29303/jpft.v5i2.1215

\begin{abstract}
This study aims to determine the effect of causal learning models on the creativity of class $X$ students of MAN 2 Mataram academic year 2018/2019. The type of research used was quasiexperimental design with untreated control group design with pretest-and posttest. The population in this study were all students of class X MIA MAN 2 Mataram. The research sample was taken by using purposive sampling technique, so that students of class X MIA 6 were selected as many as 33 people as the experimental class and the X MIA 5 class as many as 34 people as the control class. The experimental class was given treatment in the form of causal learning models and control classes using conventional learning. The instrument used to measure the creativity of students in the form of a description test as many as 6 items. The research hypothesis was tested using the t-test with a significance level of 5\%. The results of the t-test obtain a t-count value of 5.02 smaller than t_table which is equal to $2.00\left(H_{0}\right.$ is rejected and $H_{a}$ is accepted). So it can be concluded that there is the influence of causal learning models on the creativity of students. This result can be proven by the $N$-gain test, where there is an increase in creativity by $37 \%$ for the experimental class and the control class by $19 \%$ with the medium category.
\end{abstract}

Keywords: Causalitic Learning Model; Causality; Creativity

\section{PENDAHULUAN}

Ilmu pengetahuan serta teknologi pada abad ke-21 berkembang cukup pesat dan mempengaruhi segala bidang kehidupan terutama di bidang pendidikan. Perkembangan ini memunculkan tantangan baru bagi dunia pendidikan di Indonesia. Salah satu cara untuk mengahadapai tentantangan tersebut adalah dengan membekali peserta didik dengan keterampilan-keterampilan tertentu. Menurut Saavedra \& Opfer (2012:4) terdapat lima keterampilan yang harus dimiliki oleh peserta didik pada abad ke-21 yaitu, kreativitas serta inovasi, berpikir kritis (critical thinking), pemecahan masalah (problem solving), pengambilan keputusan (decision making), dan metakognitif. Sejalan dengan itu Trilling \& Fadel (2009) menyatakan bahwa penguasaan terhadap keterampilan tersebut memungkinkan penguasaan terhadap keterampilan dan kompetensi lain yang diperlukan untuk keberhasilan kehidupan di abad ke-21. Oleh karena itu sangat penting bagi peserta didik untuk memiliki keterampilan abad ke-21. Satu dari lima keterampilan abad ke-21 yang harus dimiliki peserta didik adalah kreativitas. Hal ini juga dikemukakan oleh Rawat et. al. (2012) yang menyatakan kemampuan berpikir kreatif merupakan salah satu tujuan utama seluruh pendidikan di dunia. Kreativitas dapat dipandanga sebagai process, product, person, dan press. Sebagai process kreativitas berarti kemampuan berpikir untuk membuat kombinasi baru, sebagai product kreativitas diartikan sebagai karya baru, berguna, dan dapat dipahami oleh masyarakat pada waktu tertentu, sebagai person kreativitas berarti ciri-ciri kepribadian non kognitif yang melekat pada orang kreatif, dan sebagai press artinya pengembangan kreativitas itu ditentukan oleh faktor lingkungan baik internal maupun ekternal (Aziz, 2009). Sejalan dengan itu Munandar (2012) menjelaskan keempat hal tersebut saling berhubungan antara satu sama lain, pribadi kreatif yang melibatkan diri dalam proses 
kreatif, dan dengan dukungan dan dorongan dari lingkungan, akan menghasilkan produk kreatif.

Kreativitas yang dimiliki oleh peserta didik dapat membantu peserta didik untuk berkambang dalam proses pembelajaran di kelas terutama pada pembelajaran fisika. Keterampilan berpikir kreatif mampu mambantu siswa untuk memahami suatu informasi berupa gagasan, konsep, teori, dan sebagainya (Gunawan, 2017). Menurut Gunawan et. al. (2015) fisika merupakan bagian dari sains yang memfokuskan kajiannya pada materi, energi, dan hubungan antara keduanya. Dalam pembelajaran fisika peserta didik dihadapkan dengan banyak konsep-konsep fisika yang saling berhubungan satu dengan yang lain. Untuk dapat memahami hubungan antara konsep-konsep fisika tersebut maka dibutukan kreativitas. Munandar (2012) menyatakan bahwa kreativitas adalah kemampuan untuk membuat kombinasi baru, berdasarkan data, informasi atau unsur-unsur yang ada. Sejalan dengan itu Fitriani. et al. (2017) juga menyatakan bahwa kreativitas adalah kemampuan yang dimiliki siswa yang digunakan dalam menyelesaikan suatu permasalahan melaui pengetahuan yang dimilikinya untuk menemukan banyak kemungkinan jawaban terhadap suatu masalah. Berdasarakan peryataan di atas diketahui bahwa kreativitas peserta didik dapat mempengaruhi hasil belajar peserta didik. Hal ini sejalan dengan pendapat yang menyatakan bahwa kreativitas merupakan suatu proses mental individu yang melahirkan gagasan, proses, metode ataupun produk baru yang efektif dalam berbagai bidang (Rachmawati, 2012).

Hasil Observasi yang dilakukan di MAN 2 Mataram menunjukan bahwa hasil belajar peserta didik masih kurang. Hasil belajar peserta didik yang demikian patut diduga terjadi akibat kurangnya kemampuan dalam memahami hubungan antara konsep fisika karena rendahnya kreativitas. Proses pembelajaran yang masih bersifat teacher centered menjadi salah satu sebab rendahnya kreativitas peserta didik. Kurang aktifnya peserta didik dalam kegiatan pembelajaran mengakibatkan proses pembelajaran fisika hanya berfokus pada penyelesaian contoh soal. Hal ini sesuai dengan pendapat Rokhmat (2015) yang menyatakan bahwa guru memiliki kecenderungan untuk memperkenalkan sejumlah persamaan (rumus) pada fenomena-fenomena terkait. Kegiatan pembelajaran yang berfokus pada penyelesaian soal menggunkan persamaan tidak melatih kreativitas peserta didik. Selain itu tes inteligasi maupun tes prestasi belajar kebanyakan hanya meliputi tugastugas yang harus dicari jawaban yang benar atau berpikir konvergen (Munandar, 2012). Keadaan ini mengakibatkan kemampuan berpikir divergen dan kreatif, yaitu menjajaki berbagai kemungkinan jawaban atas suatu masalah sangat jarang diukur sehingga pengembangan kemampuan kreativitas peserta didik diabaikan.

Berdasarkan permasalahan di atas maka dibutuhkan model pembelajaran yang lebih efektif dalam meningkatkan kreativitas peserta didik. Menurut Gunawan et. al. (2015) pembelajaran harus dirancang mampu merangsang peserta didik untuk berpikir dan mendorong menggunakan pikirannnya secara sadar untuk memecahkan masalah. Pembelajaran yang baik juga harus mampu mendukung siswa untuk berpikir ilmiah (Gunawan, 2015). Salah satu cara untuk dapat mengembangkan kreativitas peserta didik adalah dengan melatih peserta didik untuk berpikir kausalitik. Menurut Helmi et. al. (2017) berpikir kausalitik terdiri dari berpikir kausalitas dan analitik. Rokhmat et. al. (2013a) menyatakan dalam berpikir kausalitas peserta didik dituntut untuk mampu menentukan komponen penyebab dan berdasarkan pada kondisi 
penyebab tersebut, peserta didik dituntut untuk mampu memprediksi semua peristiwa (akibat) yang berpeluang terjadi secara deduktif. Sedangkan saat berpikir analitik, peserta didik dituntut mampu untuk mengidentifikasi bagaimana kondisi dari penyebab-penyebab yang dapat menimbulkan suatu peristiwa atau akibat tertentu berdasarkan pada pengetahuan yang sudah dimiliki yang meliputi konsep, prinsip, teori, atau hukum-hukum fisika (Rokhmat et. al,. 2012).

Berdasarkan pertimbangan tersebut peneliti berkeinginan menggunakan teknik berpikir kausalitik dalam meningkatkan kreativitas namun bukan sebagai pendekatan berpikir melainkan digunakan sebagai model pembelajaran. Sehingga patut diduga model pembelajaran kausalitik dapat meningkatkan kreativitas peserta didik. Menurut Rokhmat (2018) tahapan-tahapan kegiatan pembelajaran pada model pembelajaran kausalitik terdiri dari 4 fase pembelajaran yaitu: (1) Fase orientasi (2) Fase eksplorasi dan pengembangan konsep kausalitas (3) Fase penyusunan argumen (4) Fase evaluasi.

\section{METODE PENELITIAN}

Jenis penelitian yang dilakukan adalah quasi experimental dengan desain untreated control group design with pretestand posttest. Pepulasi penelitian ini adalah seluruh peserta didik kelas X MIA MAN 2 Mataram dengan teknik pengambilan sampel menggunakan purposive sampling, sehingga diperoleh X MIA 5 yang berjumlah 34 peserta didik sebagai kelas kontrol dan X MIA 6 yang bertujuan 33 peserta didik sebagai kelas eksperimen. Variabel dalam penelitian ini terdiri dari variabel bebas yaitu model pembelajaran kausalitik, variabel terikat yaitu kreativitas peserta didik, serta variabel kontrol yaitu materi ajar, guru yang mengajar, dan alokasi waktu pembelajaran.
Indikator Kreativitas (IK) yang diukur terdiri dari empat indikator yaitu sebagai berikut: IK-1 berpikir lancar (fluency), IK-2 berpikir luwes (flexibility), IK-3 berpikir orisinil (originality). dan IK-4 berpikir terperinci (elaboration). Rokhmat et. al. (2017:163) menjelaskan bahwa kefasihan menunjukkan berapa banyak jawaban yang diprediksi peserta didik, fleksibilitas terkait dengan bagaimana tingkat kesulitan jawaban yang dirancang, orisinalitas ditunjukkan dari tambahan jawaban yang ditulis oleh peserta didik, dan elaborasi ditunjukkan dari bagaimana peserta didik membangun ide-ide mereka.

Instrumen tes kreativitas sebelum digunakan dalam penelitian harus memenuhi beberapa syarat yaitu uji validitas, reliabilitas, tingkat kesukaran, dan daya pembeda soal. Uji analisis data yang digunakan dalam penelitian ini yaitu menggunakan uji-t dengan taraf signifikan $5 \%$ dan derajat kebebasan $\left(n_{1}+n_{2}\right)-2$ dan digunakan pula uji $\mathrm{N}$-gain untuk mengetahui peningkatan kreativitas perindikator pada kelas eksperimen maupun kelas kontrol.

Peneltian ini dilaksanakan dalam lima kali pertemuan, pertemuan pertama dan kelima digunakan untuk pretest dan posttest. Kelas eksperimen diberi perlakuan model pembelajaran kausalitik, sedangkan pada kelas kontrol menggunakan pembelajaran konvensional. Kedua kelas kemudian diberikan pembelajaran selama 3 kali pertemuan dengan alokasi waktu per pertemuan selama 135 menit atau 3 jam pelajaran pada materi usaha dan energi.

\section{HASIL DAN PEMBAHASAN}

Penelitian ini bertujuan untuk mengetahui pengaruh model pembelajaran kausalitik terhadap kreativitas peserta didik. Penelitian dilakukan dengan pemberian perlakuan berupa model pembelajaran kausalitik pada kelas eksperimen dan 
penggunaan pembelajaran konvensional pada kelas kontrol. Hasil penelitian dianalisis berdasarkan hasil pretest dan posttest pada kedua kelas sampel.

Hasil penelitian berdasarkan pretest kreativitas peserta didik kelas kontrol maupun kelas eksperimen menunjukan bahwa kreativitas peserta didik sebelum diberikan perlakuan masih rendah. Hal ini dapat dilihat dari nilai rata-rata pretest kreativitas peserta didik pada kedua kelas. Nilai rata-rata pretets kreativitas untuk kelas eksperimen yaitu 52 dan untuk kelas kontrol adalah 36.
Rendahnya nilai rata-rata pretest kreativitas peserta didik dapat disebabkan oleh beberapa hal, antara lain peserta didik belum memperoleh materi usaha dan energi sesui dengan jenjangnya serta tidak terbiasanya peserta didik untuk berpikir terbuka dalam menyelesaiakan suatu permasalahan. Data hasil pretest kreativitas kedua kelas dianalisis untuk mengetahui homogenitas data. Hasil pertest kreativitas peserta didik kelas eksperimen dan kelas kontrol dapat dilihat pada Tabel 1 berikut.

Tabel 1. Data Hasil Pretest Kelas Eksperimen dan Kontrol

\begin{tabular}{ccccccc}
\hline Kelas & Jumlah Siswa $(\mathbf{N})$ & Nilai Max. & Nilai Min. & Rata-rata & $\mathbf{s}$ & Varians \\
\hline Eksperimen & 33 & 79 & 35 & 53 & 14,78 & \\
Kontrol & 34 & 74 & 6 & 36 & 15,30 & Homogen \\
& & & & & & \\
\hline
\end{tabular}

Tabel 1 menunjukan bahwa data hasi pretest kreativitas kelas eksperimen dan kelas kontrol homogen. Berdasarkan uji homogenitas dapat disimpulkan bahwa kreativitas peserta didik setara sebelum diberikan perlakuan. Hal ini sesuai dengan pendapat Herawati et al. (2010) uji homogenitas berfungsi untuk mengetahui kesetaraan kemampuan awal kedua kelas.

Untuk mengukur pengaruh peningkatan kreativitas peserta didik setelah diberi perlakuan model pembelelajaran kausalitik dilakukan posttest dengan materi dan bobot soal yang sama seperti yang diberikan pada pretest. Hasil posttest kreativitas peserta didik yang dianalisis menunjukan nilai rata-rata kelas eksperimen yaitu 71 lebih tinggi dari nilai rata-rata kelas kontrol yaitu 48. Data posttest kreativitas kelas eksperimen dan kelas kontrol diuji normalitasnya sebagai prasyarat uji hipotesis. Hasil posttest kreativitas peserta didik kelas eksperimen dan kelas kontrol dapat dilihat pada Tabel 2 berikut.

Tabel 2. Data Hasil Posttest Kelas Eksperimen dan Kontrol

\begin{tabular}{ccccccc}
\hline Kelas & Jumlah Siswa (N) & Nilai Max. & Nilai Min. & Rata-rata & $\boldsymbol{\chi}^{\mathbf{2}}$ & Data \\
\hline Eksperimen & 33 & 97 & 42 & 71 & 4,25 & \multirow{2}{*}{ Normal } \\
Kontrol & 34 & 93 & 15 & 48 & 3,44 & \\
\hline
\end{tabular}

Tabel 2 menunjukan bahwa data hasi posttest kreativitas kelas eksperimen dan kelas kontrol normal ditentukan dari nilai $c h i$ kuadrat data kedua kelas. Berdasarkan uji normalitas dapat disimpulkan bahwa data posttest kreativitas peserta didik dapat digunakan untuk melakukan uji hipotesis. Hal ini sesuai dengan pendapat Sundayana (2016) yang menyatakan normalitas sebaran data menjadi syarat untuk menentukan jenis statistk apa yang dipakai dalam analisaan selanjutnya.

Analisis uji hipotesis yang digunakan adalah uji-t. Adapun hasil uji hipotesis diperoleh nilai $t_{\text {hitung }}$ lebih besar dari $t_{\text {tabel }}$ yaitu $5,02>2,00$. Hasil ini menunjukkan bahwa model pembelajaran kausalitik berpengaruh dalam peningkatan kreativitas 
peserta didik. Peningkatan kreativitas peserta didik setelah diberikan perlakuan model pembelajaran kausalitik disebabkan karena penerapan model kausalitik mampu meningkatkan aktifitas belajar peserta didik dimana peserta didik dilatih untuk menyelesaiakn pemasalahan yang bersifat kausalitik dan membutukan jawaban lebih dari satu. Hal ini didukung oleh pendapat Rokhmat (2015) menjelaskan bahwa pendekatan berpikir kausalitas berpusat pada aktivitas peserta didik.

Akitivitas peserta didik pada kelas eksperimen berlangsung ketika peserta didik menyelesaikan Lember Kerja Peserta Didik (LKPD) dan pada saat kegiatan diskusi.
Sejalan dengan pendapat Sahidu et. al. (2018) yang menyatakan bahwa kreativitas muncul karena adanya perhatian dan aktifitas-aktifitas mental seperti mengajukan pertanyaan, mempertimbangkan informasiinformasi baru dan ide-ide yang tidak biasanya dengan suatu pikiran terbuka.

Peningkatan kreativitas peserta didik lebih lanjut dapat dilihat dari hasil uji $\mathrm{N}$-gain per-indikator. Hasil uji N-gain secara keseluruhan indikator kreativitas pada kelas eksperimen menunjukan nilai yang lebih besar dibanding kelas kontrol. Hasil uji Ngain kreativitas peserta didik pada kelas eksperimen dan kelas kontrol dapat dilihat pada Tabel 3 berikut.

Tabel 3. Data Hasil Uji N-Gain Kreativitas Kelas Eksperimen dan Kontrol

\begin{tabular}{ccccccc}
\hline \multirow{2}{*}{ Kelas } & \multicolumn{7}{c}{ N-Gain per Indikator Kreativitas } & N-Gain Total & Kriteria \\
& IK-1 & IK -2 & IK -3 & IK -4 & & Sedang \\
\hline Eksperimen & $58 \%$ & $26 \%$ & $31 \%$ & $34 \%$ & $37 \%$ & Kurang \\
Kontrol & $37 \%$ & $14 \%$ & $12 \%$ & $16 \%$ & $19 \%$ & \\
\hline
\end{tabular}

Berdasarakan Tabel 3, terlihat presentase peningkatan kreativitas peserta didik pada kelas eksperimen lebih baik dibanding kelas kontrol untuk setiap indikator. Peningkatan kreativitas pada kelas eksperimen termasuk dalam kategori sedang, sementara peningkatan pada kelas kontrol termasuk kategori kurang. Perbedaan hasil peningkatan pada kedua kelas dikarenakan perbedaan perlakuan yang diberikan, dimana pada kelas kontrol diterapkan pembelajaran konvensional dan pada kelas eksperimen diterapkan model pembelajaran kausalitik.

Penerapan model pembelajaran kausalitik pada kelas eksperimen membuat kreativitas peserta didik berkembang lebih baik. Hal ini dapat terjadi karena dalam kegiatan pembelajaran kausalitik peserta didik dilatih untuk berpikir kausalitas dan analitik. Berpikir kausalitas dan analatik dapat meningkatakan kreativitas peserta didik. Hal ini didukung oleh pendapat Rokhmat (2013b) yang menyatakan bahwa kelebihan proses berpikir kausalitas dan analitik adalah memiliki lima kelebihan yaitu: 1) peserta didik akan terlatih untuk menganalisis fenomena fisika, 2) memahami konsep secara menyeluruh, 3) berpikir secara kritis dan sintesis, 4) berpikir secara divergen, dan 5) menjawab permasalahan berdasarkan konsep fisika. Lima kelebihan model pemebelajaran kausalitik di atas dapat menfsilitasi berkembanya setiap indikator kreativitas yang diukur.

Indikator kreativitas pada kelas kontrol yang mengalami peningkatan dalam kategori sedang adalah IK-1, sedangkan indikator IK-2, IK-3, dan IK-4 mengalami peningkatan pada kategori rendah. Berbeda dengan kelas kontrol pada kelas eksperimen indikator kreativitas yang mengalami peningkatan dengan kategori sedang adalah IK-1， IK-3， dan IK-4, sedangkan 
peningkatan indikator IK-2 berada pada kategori rendah. Pada kelas kontrol indikator kreativitas juga mengalami peningkatan pada setiap indikator, Hal ini menunjukan bahwa pembelajaran konvensional juga mampu dalam meningkatakan kreativitas peserta didik. Adapun rendanya peningkatan kreativitas peserta didik pada kelas kontrol disebabkan oleh kegiatan pembelajaran yang bersifat monoton dan pemberian soal-soal latihan yang hanya berorentasi pada penggunaan persaman (rumus) sehingga pemahaman terhadap konsep fisika dan kreativitas peserta didik dikesampingkan.

Pada kelas eksperimen peningkatan indikator tertinggi terjadi pada indikator pertama yakni berpikir lancar (fluency). Hal ini dikarenakan selama proses pembelajaran peserta didik dibiasakan untuk menyelesiakan soal-soal yang memiliki kemungkinan jawaban lebih dari satu atau kemampuan berpikir divergen. Peningkatan selanjutnya terjadi pada indikator empat yakni berpikir terperinci (elaboration). Hal ini dikarenakan model pembelajran kausaliti dapat meningkatkan kemampuan berpikir kritis dan sintesis peserta didik, sehingga peserta didik mampu memberikan penjelasan-penjelasan yang terpericih pada setiap jawabanya. Selanjutnya peningkatan juga terjadi pada indikator tiga yakni berpikir orisinil (originality). Hal ini dikarenakan model pembelajaran kausalitik mampu meningkatkan pemahaman konsep peserta didik secara menyeluruh sehingga jawaban dari peserta didik lebih berfariasi karenan menggunakan bahasanya sendiri tampa harus terpaku dengan bahasa buku.

Kemudian indikator yang mengalami peningkatan adalah indikator dua yakni berpikir luwes (flexibility). Hal ini dikarenakan penerapan model pembelajaran kausalitik dapat melatih peserta didk untuk menjawab persoalan yang diberikan menggunakan konsep-konsep fisika. Namun peningkatan indikator berpikir luwes ini masih rendah karena perserta didik cenderung tidak menambahkan konsepkonsep fisika yang terkait dalam menjawab pesoalan yang diberikan.

Hasil penelitian di atas sesui dengan pendapat Rokhamt et al. (2017), Meyer \& Lederman (2015), Anwar et al. (2012) yang menyatakan bahwa proses berpikir kausalitas mampu meningkatkan keempat indikator kreativitas. Hal ini didukung oleh pendapat Helmi et al. (2017) yang menyatakan bahwa salah satu kelebihan berpikir kausalitik ialah dapat merangsang peserta didik untuk berpikir terbuka dan menyeluruh dalam menyelesaikan masalah, sehingga peserta didik dapat memiliki pengetahuan lebih untuk menyelesaikan masalah fisika, serta dapat melatih peserta didik untuk memahami makna konsep, prinsip teori dan hukum fisika.

Dalam pelaksaan penelitian terdapat beberapa faktor yang mengakibatkan hasil penelitian menjadi kurang maksimal. Faktor pertama adalah kurang terbisanya pesert didik dengan model pembelajaran kausalitik, faktor kedua yaitu sulitnya peserta didik dalam memahami fenomena fisika yang diajarkan.

\section{PENUTUP}

Pada taraf signifikan 5\% model pembelajaran kausalitik berpengaruh dalam peningkatan kreativitas peserta didik. Uji Ngain yang dilakukan didapatkan bahwa kelas eksperimen dan kelas kontrol mengalami peningkatan kreativitas per indikatornya, tetapi kelas ekperimen memiliki peningkatan yang lebih tinggi dibandingkan dengan kelas kontrol.

Model pembelajaran kausalitik ini dapat diterapkan untuk meningkatkan kreativitas peserta didik dengan memperhatikan beberapa hal seperti alokasi waktu selama pembelajaran, pengelompokkan peserta didik, tata bahasa 
pada LKPD, serta pemaparan materi kepada peserta didik secara baik.

\section{REFERENSI}

Anwar, M., N., Aness, M., Kizar, A., Naseer, M., \& Muhammad, G. (2012). Relationship of creative thinking with the academic achievements of secondary school students. International Interdisciplinary Journal of Education, 1(3), 44.

Aziz, R. 2009. Karakteristik Pribadi Kreatif dan Kemampuan Menulis Kreatif. Anima, Indonesian Psychological Journal, 24(2), 116123.

Gunawan, G., Harjono, A., \& Sahidu, H. 2015. Pengembangan Model Laboratorium Virtual Berorientasi pada Kemampuan Pemecahan Masalah bagi Calon Guru Fisika. Jurnal Materi dan Pembelajaran fisika, 5(2), 41-46.

Gunawan. 2015. Model Pembelajaran Sains Berbasis ICT. Mataram: FKIP Universitas Mataram.

Gunawan. 2017. Keterampilan Berpikir dalam Pembelajaran Sains. Mataram: Arga Puji Press.

Fitriani, N., Gunawan, G., \& Sutrio, S. (2017). Berpikir Kreatif dalam Fisika dengan Pembelajaran Conceptual Understanding Procedures (CUPs) berbantuan LKPD. Jurnal Pendidikan Fisika dan Teknologi, 3(1), 24-33.

Helmi, F., \& Rokhmat, J. 2017. Pengaruh Pendekatan Berpikir Kausalitik Berscaffolding Tipe $2 \mathrm{~b}$ Termodifikasi Berbantuan Lks Terhadap Kemampuan Pemecahan Masalah Fluida Dinamis Siswa. Jurnal Pendidikan Fisika dan Teknologi, 3(1), 68-75.

Herawati, O. D. P., Siroj, R. A., \& Basir, M. D. 2010. Pengaruh Pembelajaran Problem Posing Terhadap Kemampuan Pemahaman Konsep Matematika Siswa Kelas XI IPA SMA
Negeri 6 Palembang. Jurnal Pendidikan Matematika, 4(1), 70-80.

Meyer, A. A., and Lederman, N. G. (2015). "Creative Cognition on Secondary Science: An exploration of divergent thinking in science among adolescents".International Journal of Science Education. Retrieved from: http://dx.doi.org/10.1080/09500693.2 015.1043599 .

Munandar, U. 2012. Pengembangan Kreativitas Anak Berbakat. Jakarta: Rineka Cipta.

Rachmawati, Y. 2012. Strategi Pengembangan Kreativitas Pada Anak. Prenada Media.

Rawat, K. J., Qazi, W., \& Hamid, S. (2012). Creativity and education. Academic Research International, 2(2), 264.

Rokhmat, J. 2013a. Kemampuan Proses Berpikir Kausalitas dan Berpikir Analitik Mahasiswa Calon Guru Fisika. Jurnal Pengajaran MIPA, 18(1), 78-86.

2013b. Peningkatan Kemampuan Pemecahan Masalah Mahasiswa Calon Guru Fisika melalui Berpikir Kausalitas dan Analitik [The Increase of Problem-solving Ability of Physics Pre-service Student through Causality and Analytic Thinking]. Disertasi Doktor pada Pendidikan IPA. Universitas Pendidikan Indonesia: tidak diterbitkan.

2015. Penerapan pendekatan berpikir kausalitik ber-scaffolding dalam meningkatkan KPM hukum Newton tentang gerak. In Seminar Nasional Fisika, 12(3), 76-82.

2018. Model Pembelajaran Kuasalitik. Mataram: Arg Puji Press.

Rokhmat, J., Marzuki, M., Hikmawati, H., \& Verawati, N. N. S. P. 2017. The Causal Model in Physics Learning with a Causalitic-thinking Approach to Increase the Problem-solving Ability of Pre-service Teachers. Pertanika 
Journal of Social Science and Humanities JSSH, 25(S), 153-168.

Rokhmat, J., Setiawan, A., \& Rusdiana, D. 2012. Pembelajaran Fisika Berbasis Proses Berpikir Kausalitas dan Berpikir Analitik (PBK-BA), Suatu Pembiasaan Berpikir Secara Terbuka. In Seminar Nasional VII Pendidikan Biologi, 9(1), 391-397.

Saavedra, A., \& Opfer, V. 2012. Teaching and Learning 21st Century Skills: Lessons from the Learning Sciences. A Global Cities Education Network Report. New York, Asia Society.

Sahidu, H., Gunawan, G., Rokhmat, J., \& Rahayu, S. (2018). Pengembangan Perangkat Pembelajaran Fisika Berorientasi Pada Kreativitas Calon Guru. Jurnal Pendidikan Fisika dan Teknologi, 4(1), 1-6.

Sundayana, R. 2016. Statistik Penelitian Pendidikan. Bandung: Alfabeta.

Trilling, B., \& Fadel, C. 2009. 21st century skills: Learning for life in our times. John Wiley \& Sons. 